ORIGINAL ARTICLE

\title{
Genomewide scan identifies susceptibility locus for dyslexia on Xq27 in an extended Dutch family
}

C G F de Kovel, F A Hol, J G A M Heister, J J H T Willemen, L A Sandkuijl, B Franke, G W Padberg

J Med Genet 2004;41:652-657. doi: 10.1136/jmg.2003.012294

See end of article for authors' affiliations

Correspondence to: Dr C G F de Kovel, University Leiden,

Theoretical Biology

Kaiserstraat 63, 231 1 GP

Leiden, The Netherlands: dekovel@rulsfb.leidenuniv. ne

Received 10 July 2003

Revised 26 March 2004

Accepted 13 April 2004
Context: Dyslexia is a common disorder with a strong genetic component, but despite significant research effort, the aetiology is still largely unknown.

Objective: To identify loci contributing to dyslexia risk.

Methods: This was a genomewide linkage analysis in a single large family. Dutch families with at least two first degree relatives suffering from dyslexia participated in the study. Participants were recruited through an advertisement campaign in papers and magazines. The main outcome measure was linkage between genetic markers and dyslexia phenotype.

Results: Using parametric linkage analysis, we found strong evidence for a locus influencing dyslexia on Xq27.3 (multipoint lod=3.68). Recombinations in two family members flanked an $8 \mathrm{cM}$ region, comprising 11 currently confirmed genes. All four males carrying the risk haplotype had very low scores on the reading tests. The presentation in females was more variable, but $8 / 9$ females carrying the risk haplotype were diagnosed dyslexic by our composite score, so we considered the putative risk allele to be dominant with reduced penetrance. Linkage was not found in an additional collection of affected sibling pairs.

Conclusions: A locus influencing dyslexia risk is probably located between markers DXS1227 and DXS8091 on the X chromosome, closely situated to a locus indicated by a published genome scan of English sibling pairs. Although the locus may not be a common cause for dyslexia, the relatively small and gene poor region offers hope to identify the responsible gene.
D evelopmental dyslexia is defined as a distinct learning impairment characterised by difficulties in single word decoding. Dyslexics show profound difficulties in learning to read and/or write despite otherwise normal intelligence and cognitive skills. Multiple family and sibling studies, investigating both a global dyslexia phenotype and specific cognitive abilities within the dyslexia spectrum, have consistently demonstrated that genetic factors are of major aetiological significance for development of the condition. Linkage studies have indicated susceptibility loci on a number of chromosomes, including $1,{ }^{1} 2,{ }^{23} 3,{ }^{4} 6,{ }^{5} 7,,^{7} 15,{ }^{8-10}$ and $18 .{ }^{11}$ The genetic studies were not long ago reviewed by Schulte-Körne ${ }^{12}$ and Fisher \& deFries. ${ }^{13}$ Recently, Taipale et a ${ }^{14}$ identified a gene on 15q that is associated with dyslexia.

The prevalence of dyslexia has been found to be higher in male than in female schoolchildren. The ratio of boys to girls among dyslexics varies between studies, depending on method of ascertainment and on the applied definition of dyslexia. In a large, presumably unbiased collection of Dutch schoolchildren, an M:F ratio of around 2:1 was found. ${ }^{15}$ The total prevalence of dyslexia in this survey of Dutch 12 year olds was $3.6 \%$.

A possible cause for sex bias in congenital disorders is the involvement of X linked loci. Segregation studies, however, indicate that the disorder is usually inherited as autosomal dominant ${ }^{16}{ }^{17}$ Recently, in a genomewide scan on a collection of clinic ascertained sibling pairs from the UK, some evidence was found for a quantitative trait locus (QTL) for single word reading on Xq26, although stronger signals were found at other chromosomal locations. ${ }^{11}$ A recessive allele of an $\mathrm{X}$ linked gene increasing the risk for dyslexia could explain why (hemizygous) males are more commonly or more severely ${ }^{18}$ affected than females. Other explanations for the skewed sex ratio, however, involving a role of male specific hormones during development interacting with an autosomal locus, for example, cannot be ruled out. ${ }^{19}$

In the current study, we investigated a large Dutch speaking family in which dyslexia appeared to be segregating (fig 1). Diagnosis was based on the combination of scores on a small number of tests, as described below. We carried out a genomewide, 400 marker linkage study including the $\mathrm{X}$ chromosome. Parametric linkage analysis was used to identify possible genes predisposing for dyslexia. Regions with suggestive linkage were checked in a collection of affected sibling pairs.

\section{MATERIALS AND METHODS \\ Subjects}

As part of a large multidisciplinary research effort into different aspects of dyslexia, an advertisement campaign was set up to collect multiplex dyslexia families. Advertisements were published in regional and national papers and magazines. Families were ascertained when at least two first degree relatives had a school history of reading problems. In this way, a panel of predominantly nuclear families was collected. In addition, a few large three generation families displaying apparent autosomal dominant inheritance could be identified, including the family described in this paper. Informed consent was obtained from all participants and the study was approved by the local ethics committee (CWOM) of the University Medical Centre Nijmegen under CWOM-nr 9811-025. The family described in this paper included 29 persons of white descent who were all willing to cooperate (fig 1). Loci with suggestive lod scores were checked in a subset from our collection of affected sibling pairs and their parents, who had been ascertained and tested in the same

Abbreviation: QTL, quantitative trait locus 


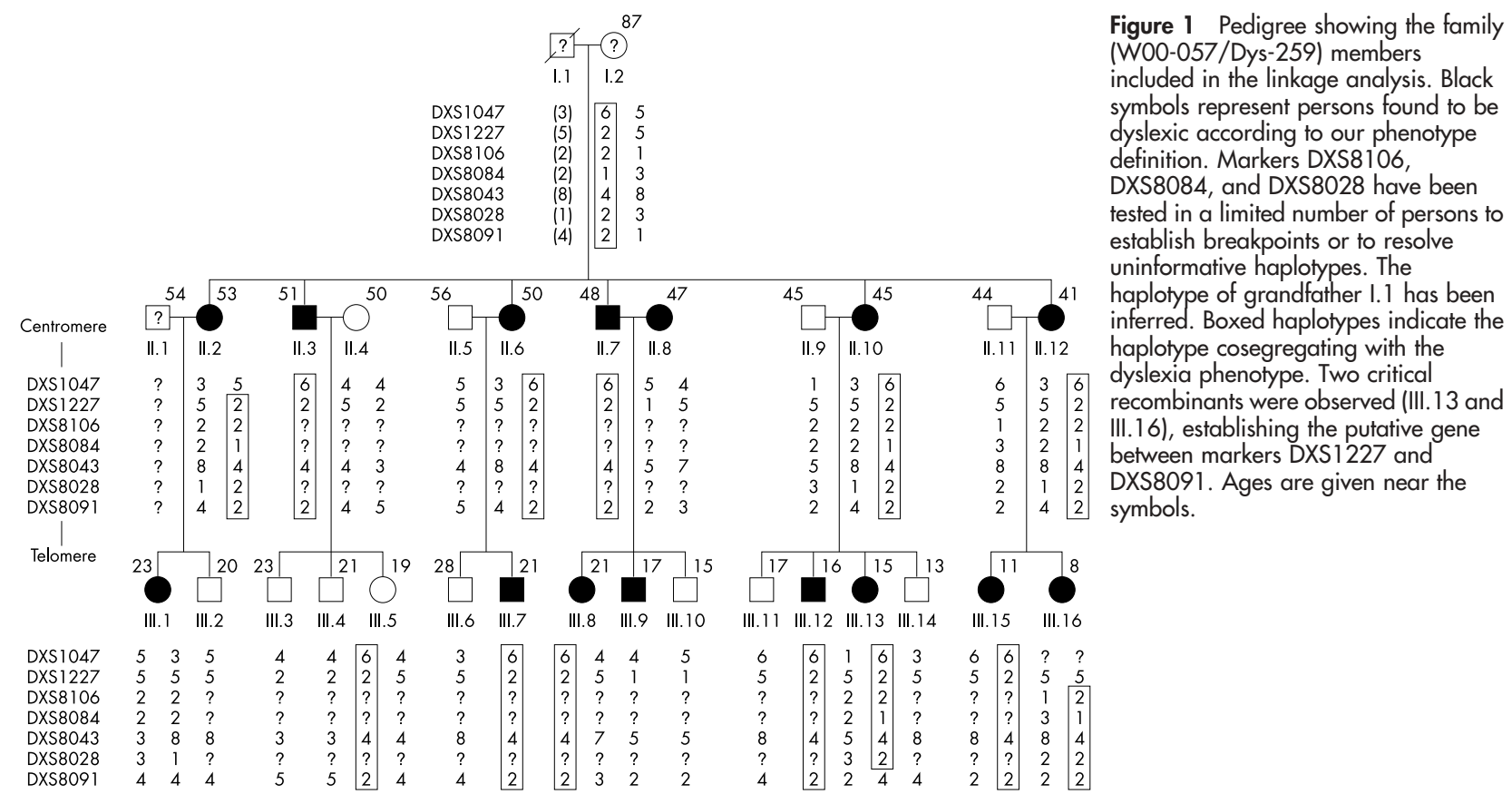

manner as the large family. As linkage results were found for an $\mathrm{X}$ linked locus with seemingly a clearer phenotype in males, we selected 67 pairs of affected brothers and their mothers from our sibling pair collection for this initial check. A genomewide linkage scan was also carried out for two other extended families. As the linkage results did not coincide with those of the family described in this paper, the results will be described elsewhere.

\section{Phenotypic measures}

The subjects were administered a small battery of tests, as described below, in individual sessions. ${ }^{20}$

\section{Single word reading test}

This is a standardised test, often used for testing dyslexia in schools. ${ }^{21}$ The subjects have to read across columns of increasingly difficult, unrelated words within a time constraint of 1 minute. Only correctly pronounced words are scored. This test measures a combination of speed and accuracy, as many adults who have had reading difficulties in school can eventually reach normal levels of accuracy, but are likely to remain significantly slower than normal.

\section{Non-word reading test}

Subjects must read across columns of increasingly difficult non-existing, but pronounceable words with a time constraint of 2 minutes. ${ }^{22}$ Again, the score was the number of words pronounced correctly within the time constraint. In this test, the lexical route of reading, which according to some theories is independent of the phonological route, is eliminated.

\section{Verbal competence}

This test is part of the Dutch version of the Wechsler Adult Intelligence Test. ${ }^{23}$ It tests the ability of the subject to express him/herself verbally. The subject is offered two words and is asked to describe as concisely as possible the similarity between them. Examples are car-aeroplane or courage-cowardice. Other tests were administered as well, but they were not used in this study and will therefore not be discussed. Adult subjects were asked to fill out a questionnaire concerning school history and related issues. One of the parents filled out a similar questionnaire for the children within the household. We also obtained a list of presumably affected members from the contact person.

\section{Diagnostic criteria}

The control group consisted of $56016-17$ year old pupils from four different levels in Dutch secondary education: VBO, MAVO, HAVO, and VWO (roughly equivalent to technical training, O-levels, higher general secondary education, and A-levels, respectively). Prior to further analysis, the scores of these pupils were weighted relative to the actual distribution of pupils over those levels in Dutch schools. Scores from test subjects were expressed as percentile scores relative to this weighted control group.

We used a phenotype definition following the criteria designed by the Dutch Dyslexia Programme. Affected status according to this definition required scoring below the normative 10th percentile on the word or the non-word reading test or scoring below the 25 th normative percentile on both of the tests. Affected status could also be assigned based on a discrepancy criterion: it required the word or nonword reading score to be $\geqslant 60$ percentage points below the normalised score on the verbal competence test (Kuijpers et $\left.a l^{20}\right)$. The discrepancy criterion was included to identify people who had adequately compensated their reading problems, but still scored below what could be expected based on their general verbal competence, when pressed for time. These criteria classified over $20 \%$ of the weighted control group as dyslexic. An almost identical combination of criteria was used by Grigorenko, ${ }^{8}$ with an almost identical percentage of affected individuals in the control population. The criteria used by the Dutch dyslexia programme to identify dyslexics are intentionally rather wide, so as not to miss compensated adults. ${ }^{24}$ Criteria designed to select children for remedial teaching will probably differ from criteria designed to identify persons with a predisposition for dyslexia for research purposes. ${ }^{8}$

For all adults and for schoolchildren having completed their first year of secondary school, the control group was used to assign affectedness status. For younger children, published scoring criteria were used..$^{21} 22$ 


\section{Genotyping}

EDTA blood was collected from each person and DNA was extracted by a standard extraction method. ${ }^{25}$ The genome was screened using the set of 400 CA repeat markers (LMS-MDI0 v2.5; Applied Biosystems, Foster City, CA, USA). The average heterozygosity of these markers was 0.76. The average distance between markers was $10 \mathrm{cM}$. Intermarker distances for multipoint analysis were obtained from Marshfield genetic maps (http://research.marshfieldclinic.org/). Three additional markers, DXS8028, DXS8084, and DXS8106 were selected for fine mapping purposes from the public databases on chromosome $X$. Six markers in the region that showed strongest evidence for linkage were analysed in 67 affected male sibling pairs and their mothers (DXS1227, DXS8106, DXS8084, DXS8043, DXS8028, and DXS8091), which were a subset from our collection of families. The analysis of the markers was according to the protocol provided for the LMSMD10 v2.5 ${ }^{26}$ with some small modifications. PCRs were performed in $10 \mathrm{l}$ reaction volumes containing about $40 \mathrm{ng}$ of genomic DNA, 5 pmol of each primer, $2.5 \mathrm{mmol} / \mathrm{l} \mathrm{MgCl}_{2}$, $250 \mathrm{~mol} / \mathrm{l}$ each dNTP, $10 \mathrm{mmol} / \mathrm{l} \mathrm{Tris} \mathrm{HCl}$ ( $\mathrm{pH} 8.3$ ), $50 \mathrm{mmol} / \mathrm{l}$ $\mathrm{KCl}$, and $0.4 \mathrm{U}$ of Taq polymerase (AmpliTaq ${ }^{\mathrm{TM}}$ Gold; Applied Biosystems). The PCRs had an initial denaturation stage of 12 minutes at $95^{\circ} \mathrm{C}$, followed by 10 cycles of 15 seconds at $94^{\circ} \mathrm{C}, 15$ seconds at $55^{\circ} \mathrm{C}$ and 30 seconds at $72^{\circ} \mathrm{C}$, then 22 cycles of 15 seconds at $89^{\circ} \mathrm{C}, 15$ seconds at $55^{\circ} \mathrm{C}$, and 30 seconds at $72^{\circ} \mathrm{C}$, and a final extension step at $72^{\circ} \mathrm{C}$ for 10 minutes. Reactions for each marker were performed separately, with products being pooled into size specific sets before typing. Markers were typed on an ABI 3100 sequencer (Applied Biosystems) using the Genescan ${ }^{\mathrm{TM}}$ and Genotyper $^{\mathrm{TM}}$ software (Applied Biosystems). Allele binning was done with the Excel macro Linkage Designer (designed by G van Camp). ${ }^{27}$ Mendelian inheritance was checked with PedCheck software. ${ }^{28}$

\section{Linkage analysis}

Parametric linkage analyses were performed using version 5.2 of the LINKAGE program. Two point lod scores were calculated using MLINK of the LINKAGE package version 5.1. ${ }^{29}$ Multipoint analyses were carried out with the LinkMap program $^{30}$ in regions that had lod scores $>1.5$, followed by inspection of haplotypes, which were created in the software program Cyrillic 2.1.

There were two models used in the linkage analysis, with the following characteristics. Model 1: an autosomal dominant model with sex dependent penetrance $(0.02,0.95$, and 1.00 for unaffected, heterozygous, and homozygous males; $0.005,0.85$, and 0.95 for unaffected, heterozygous, and homozygous females), and an allele frequency of $2 \%$, assuming a $5 \%$ disease prevalence and a $1.5 \mathrm{M}: \mathrm{F}$ ratio. Model 2: an autosomal dominant model, assuming high phenocopy numbers (penetrances 0.16, 0.95, and 1.0 for males; 0.16, 0.85, and 0.95 for females). Model 1 is based on published segregation analyses for dyslexia. ${ }^{17}$ Model 2 assumes $19 \%$ prevalence of dyslexia and an almost equal sex ratio, and is based upon the frequency of the phenotype in the control group. ${ }^{20}$ For $\mathrm{X}$ linked loci, identical penetrance values were used (M: 0.02 and 0.95; F: 0.005, 0.85, and 0.95), although these result in slightly lower prevalences and less skewed sex ratios. Because a genetically heterogeneous disorder such as dyslexia makes it difficult to choose the appropriate parameter set, we also conducted a nonparametric linkage analysis in Merlin 0.10.1 (options Minx-NPL), which uses Kong-Cox function ${ }^{31}$ to convert Z scores into lod scores and associated p values).

Linkage of the locus to the dyslexia phenotype in the affected sibling pairs was assessed by non-parametric linkage using Genehunter.

\section{Mutation analysis}

Mutation analysis of candidate genes in the region identified by high lod scores was performed by forward and reverse sequencing of the coding regions of the genes of at least one male family member carrying the risk haplotype and at least one male family member not carrying the risk haplotype.

\section{RESULTS}

The family consisted of 33 people, 29 of whom could be included in this study. Of these 29 subjects, five males and 10 females were classified as dyslexic, based on the tests described above. One of those females was an unrelated spouse. The grandmother of the family (I.2), reportedly, could not read (test scores can be found in table 1).

Linkage results are based on 374 of 400 markers that showed reliable results. The highest lod score by far, and the only one exceeding the threshold lod score of 3, was on the X chromosome at marker DXS8043 with Model 1. The two point lod score was 3.38 (multipoint lod score 3.68) at $\theta=0.00$ of marker DXS8043 (fig 2). The high phenocopy Model 2 also indicated only this locus, although as expected with a lower two point lod score of 2.61. Neither model indicated other loci with lod scores exceeding 1.5. None of the previously described candidate loci on chromosomes 1, 2, 3 , 6, 15, and 18 (see text), showed evidence for linkage. The non-parametric linkage analysis by Merlin resulted in $\mathrm{Z}=8.75$ at marker DXS8043 with $\mathrm{p}<0.0001$. Converted to lod, this was 1.95, $\mathrm{p}=0.0014$ (fig 2).

As two key recombinants flanked the region around marker DXS8043, we tested three extra markers between the two breakpoints in the key recombinants and their ancestors, the extra markers being DXS8028, DXS8084, and DXS8106. The chromosomal region was narrowed down to about $8 \mathrm{cM}$ between marker DXS1227 (proximal) and marker DXS8091 (distal) (fig 1). This region encompasses chromosomal band Xq27.3 and small parts of the flanking bands Xq27.2 and Xq28.

\section{Sex dependent expression of the $X$ linked allele}

Depending on the dominance of the alternative alleles, $\mathrm{X}$ linked genes may cause differences in prevalence among males and females. According to our criteria all four males carrying the risk haplotype and eight of the nine women carrying the risk haplotype were classified as dyslexic. This argues for a dominant effect of the risk allele, yet it is possible that heterozygous females are less severely affected than hemizygous males. To investigate this we returned to the test scores. We added up the test results for single word reading and for non-word reading to create a single score, as these tests are the most important components for the dyslexia criteria. An analysis of covariance was carried out with carrier status and sex as fixed factors, and age as a covariant. Age had no significant effect on test results $(p=0.116)$. As expected, a significant effect of carrier status on test results was found $(p=0.002)$. No significant effect of sex $(p=0.563)$ was found, but there was a significant interaction between sex and carrier status $(p=0.046)$; the difference in test scores between male carriers and non-carriers was significantly larger than the difference between female carriers and non-carriers. Non-carrier males scored a mean (SD) of 178 (31) (corresponding $\mathrm{z}$ score $=0.2$ ) on the combined test, non-carrier females scored 160 (34) (zscore $=-0.5)$. Among the carriers, males scored on average 79 (17) (z score $=-3.1)$ and females 125 (58) (z score $=-1.6$ ) (fig 3 ). The effect of the allele on reading ability, therefore, seemed to be larger in hemizygous men (decline of $3.3 \mathrm{SD}$ ) than in heterozygous women (decline of $0.7 \mathrm{SD})$. The pattern for the males seemed very straightforward: all four carriers scored below the fifth percentile on 
Table 1 Ages and scores of family members on word reading, non-word reading, and verbal competence tests, expressed as percentile relative to age matched controls, and dyslexic status according to criteria described in the text, according to the contact, and according to the questionnaire that was completed by either the person s themselves or by one of their parents.

\begin{tabular}{|c|c|c|c|c|c|c|c|}
\hline Patient ID & $\begin{array}{l}\text { Age } \\
\text { (years) }\end{array}$ & $\begin{array}{l}\text { Word reading } \\
\text { (percentile) }\end{array}$ & $\begin{array}{l}\text { Non-word } \\
\text { reading }\end{array}$ & $\begin{array}{l}\text { Verbal } \\
\text { competence }\end{array}$ & $\begin{array}{l}\text { Dyslexic } \\
\text { (broad) }\end{array}$ & $\begin{array}{l}\text { Report by } \\
\text { contact }\end{array}$ & $\begin{array}{l}\text { Questionnaire } \\
\text { (self or parent) }\end{array}$ \\
\hline I. 1 & - & - & - & - & - & - & - \\
\hline 1.2 & 87 & - & - & - & - & - & - \\
\hline II. 1 & 54 & - & - & - & - & - & - \\
\hline II. 2 & 53 & 28 & 18 & 84 & $Y$ & $N$ & $\mathrm{~N}$ \\
\hline II. 3 & 51 & 5 & 3 & 40 & $Y$ & - & - \\
\hline II. 4 & 51 & 37 & 81 & 40 & $\mathrm{~N}$ & $N$ & $\mathrm{~N}$ \\
\hline II. 5 & 56 & 75 & 24 & 7 & $\mathrm{~N}$ & $N$ & $\mathrm{~N}$ \\
\hline II. 6 & 51 & 53 & 11 & 98 & $\mathrm{~N}$ & $N$ & $\mathrm{~N}$ \\
\hline 11.7 & 48 & 1 & 1 & 47 & $Y$ & $Y$ & $Y$ \\
\hline II. 8 & 47 & 37 & 73 & 100 & $Y$ & $N$ & $Y$ \\
\hline 11.9 & 45 & 89 & 81 & 91 & $N$ & $N$ & $\mathrm{~N}$ \\
\hline II. 10 & 45 & 31 & 12 & 100 & $Y$ & $Y$ & $Y$ \\
\hline II. 11 & 44 & 94 & 43 & 84 & $N$ & $N$ & $\mathrm{~N}$ \\
\hline II. 12 & 41 & 1 & 1 & 7 & $Y$ & $Y$ & $\mathrm{~N}$ \\
\hline III. 1 & 23 & 5 & 5 & 33 & $Y$ & $Y$ & $Y$ \\
\hline III.2 & 20 & 69 & 98 & 33 & $\mathrm{~N}$ & $N$ & $\mathrm{~N}$ \\
\hline III. 3 & 23 & 82 & 75 & 84 & $N$ & - & $\mathrm{N}$ \\
\hline III. 4 & 21 & 72 & 52 & 91 & $N$ & $Y$ & - \\
\hline III.5 & 19 & 100 & 99 & 40 & $\mathrm{~N}$ & $\mathrm{~N}$ & $\mathrm{~N}$ \\
\hline III.6 & 28 & 80 & 81 & 70 & $\mathrm{~N}$ & $N$ & $\mathrm{~N}$ \\
\hline III.7 & 24 & 1 & 1 & 70 & $Y$ & $Y$ & $Y$ \\
\hline III.8 & 21 & 53 & 19 & 98 & $Y$ & $\mathrm{~N}$ & $Y$ \\
\hline III.9 & 17 & 2 & 3 & 70 & $Y$ & $Y$ & $Y$ \\
\hline III. 10 & 15 & 40 & 26 & 70 & $N$ & $N$ & $Y$ \\
\hline III. 11 & 17 & 40 & 26 & 84 & $N$ & $Y$ & $Y$ \\
\hline III. 12 & 16 & 1 & 1 & 63 & $Y$ & $Y$ & $Y$ \\
\hline III. 13 & 15 & 5 & 5 & 47 & $Y$ & $Y$ & $Y$ \\
\hline III. 14 & 13 & 40 & 81 & 78 & $N$ & $N$ & $\mathrm{~N}$ \\
\hline III. 15 & 11 & 2 & 13 & 19 & $Y$ & - & $\mathrm{N}$ \\
\hline III. 16 & 8 & 1 & 1 & 1 & $Y$ & - & $\mathrm{N}$ \\
\hline
\end{tabular}

- Unknown.

A discrepancy with one of the self reports was present in six cases; a discrepancy with both self reports was not found.

word and non-word reading, and all were dyslexic according to their own statement. Of the carrier women, II.12, her daughters III.15 and III.16, and niece III.13 scored below the fifth percentile on word reading, and II.12, III.13, and III.15 also on non-word reading, so these women resembled the males. Subjects II.12 and III.13 were dyslexic according to their own report; the other two ( 8 and 11 years old) reportedly had difficulties in school, but the mother was

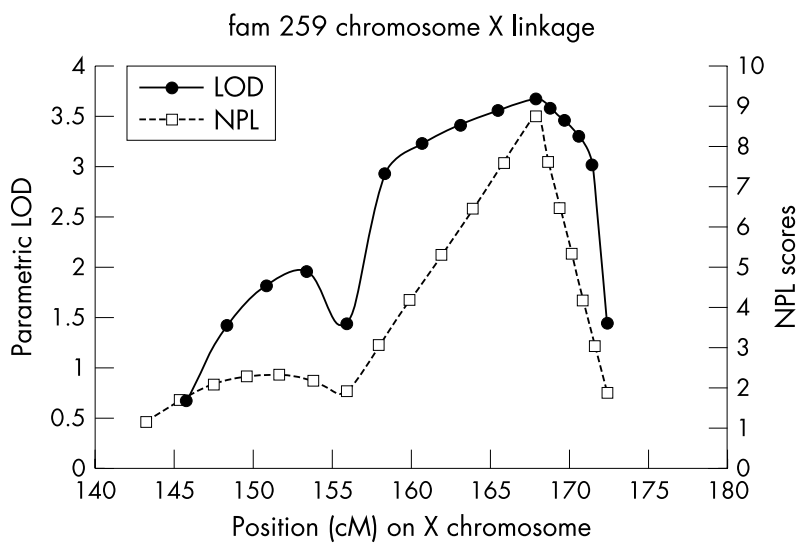

Figure 2 Family W00-057. Solid line, multipoint mapping results (LINKMAP) for parametric linkage of dyslexia between markers DXS1047 and DXS8091 with Model 1: 2\% frequency disease allele and penetrances $0.02,0.95$, and 1.0 for males, and $0.005,0.85$, and 0.95 for females. Dotted line, non-parametric linkage results (MERLIN) for the same. not sure whether this was due to dyslexia, and the girls had not been tested. Four other females (II.2, II.6, II.10, and III.8) were identified as dyslexic because of the discrepancy between non-word reading and their verbal competence. Of these, II.10 and III.8 reported to have had spelling problems during elementary education, but few difficulties later in life, while II.6 reported only mild problems with reading and spelling during elementary school and with languages during secondary education. One woman (III.5) carried the risk haplotype, but scored far above average (99th and 100th percentile) on word and non-word reading. She reported no real problems at school. Although the allele seemed dominant, its effect appeared more variable in females than in males. Two persons (III.1 and III.9) were found to be dyslexic, but did not carry the risk haplotype. Both had a severe phenotype with word and non-word reading below or equal to the fifth percentile. At least one of those had an affected parent not related to the family. Obviously, other causes for dyslexia played a role in this family (individual test scores can be found in table 1).

\section{Investigation of $\mathrm{Xp27}$ locus in affected sibling pairs}

The affected siblings were on average 17 years old (range 840 years). Their mean (range) test scores were 61.64 (7-115) for word reading, 39.9 (1-78) for non-word reading, and 101.5 (8-186) for the sum of both. For comparison, in our control population the averages were 87 (47-116) for word reading, 81 (20-116) for non-word reading, and 168 (74-232) for the sum.

The result of the non-parametric linkage analysis (NPL-all) for the dyslexia phenotype was a $\mathrm{z}$-value of -1.64 at marker 


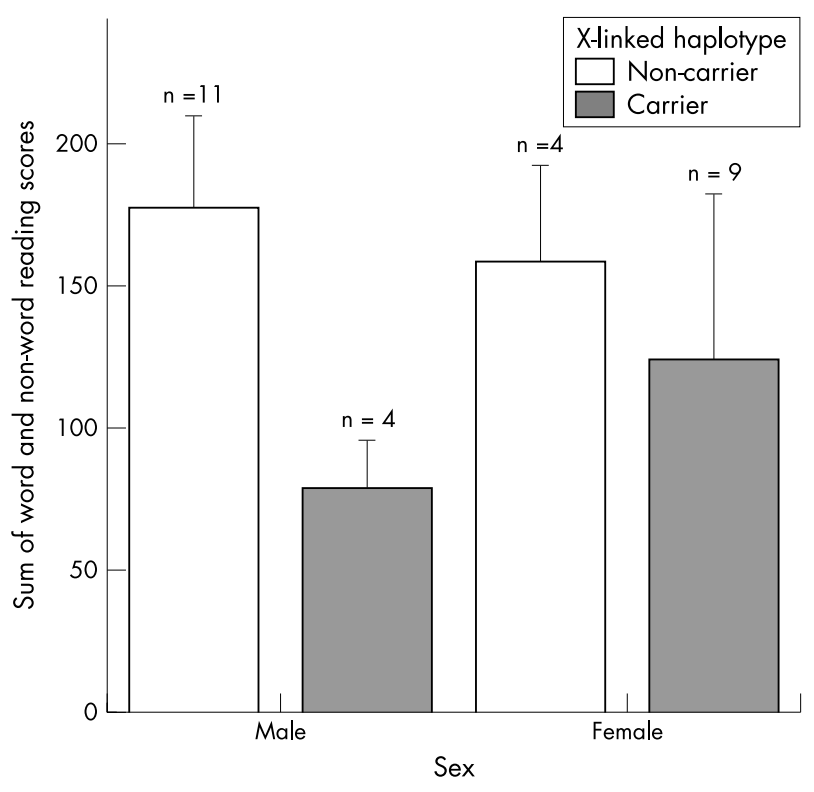

Figure 3 Sum of scores on word and non-word reading for carriers (dark bars) and non-carriers (light bars) of the $\mathrm{X}$ linked risk haplotype. Error bars show one standard deviation, the horizontal line indicates the average score of the weighted control group (173). The effect of carrier status was significantly larger in males than in females $(p=0.033)$.

DXS8043 with associated p value $=0.94$, so there was no evidence for linkage to this locus in the general Dutch population.

\section{Mutation analysis}

No mutations were found to segregate with dyslexia in the coding regions of the genes FMR1, Cxorf1, DKFZp574M2010, or KIAA1854.

\section{DISCUSSION}

\section{Candidate locus for dyslexia on Xq27-28}

Reading difficulties are in part due to genetic influences. Linkage studies have indicated a number of chromosomal regions, which shows that dyslexia is a genetically heterogeneous trait and many genes can contribute to the phenotype. To date, a gene affecting dyslexia has been identified in only one of those regions. The present study cannot confirm any of the previous reports, with the possible exception of some results from a large genome scan on sibling pairs by Fisher et al. ${ }^{11}$ In that study, possible linkage for a reading ability QTL was found to the region Xq26 around marker DXS1047 (position $82.07 \mathrm{cM}$ on the Marshfield map) with a broad peak. Our current study found high lod scores around marker DXS8043 at position $94.2 \mathrm{cM}$ on the Marshfield map (Xq27.3). Broad regions and flat peaks are not unusual in studies of neurological disorders, ${ }^{32}$ so these results may well point to the same gene.

We were able to narrow the chromosomal region in which the putative gene should be found to a size of about $8 \mathrm{cM}$ (sex average map), not including marker DXS1047 found by Fisher et al. The region spans band Xq27.3 and parts of flanking bands Xq27.2 and Xq28. Because of the possibility of phenocopies among the key recombinants, the boundaries should be considered with some caution.

\section{Candidate genes}

This is a relatively gene poor region: only 11 confirmed genes are reported and an additional eleven predicted (Public and Celera databases, Map View Build 33, October 2003). The first marker outside the risk haplotype at the telomeric side
(DXS8091) lies within the first intron of the FMR2 gene, a gene involved in fragile $\mathrm{X}$ mental retardation. However, the coding regions of the gene are outside our interval. The other currently identified genes in this region are $M A G E C 3$, $M A G E C 1$, and MAGEEl, genes from a melanoma antigen family; MYCL3, a pseudogene with homology to an avian viral oncogene, ${ }^{33} R R M 2 P 4$, a ribonucleotide reductase pseudogene; $F M R 1$, a gene involved in fragile $\mathrm{X}$ mental retardation; Cxorfl, a gene expressed in the hippocampus; ${ }^{34}$ and KIAAl854, FLJ25736, and DKFZp547M2010, coding for hypothetical proteins. The MAGE family genes in this region seem to be sperm specific. ${ }^{35}$ FLJ25736 protein has also been isolated from human testes. ${ }^{36}$ These genes do not seem to be likely candidates for dyslexia susceptibility. Hypothetical protein KIAAl 854 is expressed in brain and is probably identical to the product of putative gene SLITL1, a gene assumed to be involved in formation and maintenance of the nervous system. ${ }^{37}{ }^{38}$ Trinucleotide repeat expansions in FMRI, and subsequent silencing of the gene, are associated with mental retardation and learning disabilities. FMRl contains an mRNA binding region and is involved in neurone development. ${ }^{39}$ The FMRl, KIAA1854, and Cxorfl genes can be considered plausible candidates. The function of DKFZp547M2010 is currently unknown, but it is expressed in the hippocampus. It shows high homology with the product of the Mus musculus gene SLITRk4, which controls neurite outgrowth, and is expressed in brain and hippocampus. We therefore considered DKFZp547M2010 to be a candidate as well.

Mutation analysis of the coding regions CXorf, KIAA1854, FMRI, and DKFZP547M2010 revealed no polymorphisms that segregated with dyslexia.

\section{Degree of dominance of the putative locus}

The results of this study suggest that the locus on Xq27.3 contains a risk factor for dyslexia with sex dependent expression. Alhough eight of nine carrier women were designated dyslexic according to our tests, not all had reported themselves as dyslexic. The phenotype seemed more variable in the nine women than in the four males. The sample is of course very small, so the conclusions for sex differences are tentative. A more varied phenotype in women for an X linked gene can, however, easily be explained by the mosaicism of $\mathrm{X}$ inactivation, ${ }^{40}$ but other explanations of the sex differences in expression are also possible. As all except one of the carrying females were found to be dyslexic, we would consider this factor dominant with sex related differences in penetrance and expression.

\section{Importance of current results for the general Dutch population}

Alhough segregation analyses and other linkage studies have shown that in most populations $\mathrm{X}$ linked loci are not of major importance for dyslexia or its components, ${ }^{17}$ it cannot be ruled out that dyslexia can be a polygenic trait to which $\mathrm{X}$ linked genes contribute. Most probably, it is a genetically heterogeneous trait. We found the factor on Xq27.3 to tend towards dominance, and this cannot explain the consistently reported male bias. However, the degree of dominance may vary with the genetic background in which the allele finds itself. It is also possible that other mutations in the same gene act as recessive alleles, thus contributing to a male bias.

Fisher et al found a locus at Xq26 with a Haseman-Elston analysis of single word reading in their UK sample of affected sibling pairs, but not in their US sample. We also found no indication for a major contribution of this locus to dyslexia no its components in our sample of sibling pairs. Most probably, the mutation is not very common, but not completely unique to our family either. 
In summary, there were strong indications from our linkage study that the Dutch speaking family described in this paper carried a risk factor for dyslexia on the $\mathrm{X}$ chromosome in the $8 \mathrm{cM}$ region between markers DXS1227 and DXS8091. The factor behaved as a dominant allele with a variable effect in females. Analysis of this locus in an additional collection of 67 male sibling pairs showed that the locus does not appear to be of major importance in our Dutch sample. Findings by Fisher et al, however, suggest it plays a minor role in UK populations.

\section{ACKNOWLEDGEMENTS}

We are grateful to the families for participating in this study. We thank $\mathrm{H}$ Brunner for useful discussions, $\mathrm{N}$ Blokdijk for help in collecting the samples, B Franke for help with administering the tests, and C Kuijpers for help with interpreting the test scores. We also thank B Simmelink and M Schijvenaars for help with sequencing. This work was funded by grant 200-62-305 from the Dutch Research Association (NWO), division Geesteswetenschappen.

\section{Authors' affiliations}

C G F de Kovel, Department of Theoretical Biology, University of Leiden, NL-2311 GP Leiden, The Netherlands

F A Hol, J G A M Heister, J J H T Willemen, B Franke, Department of Human Genetics, University Medical Centre Nijmegen, NL-6500 HB Nijmegen, The Netherlands

L A Sandkuijl, Department Medical Statistics and Bio Informatics, Leiden University Medical Centre, NL-2300 RC Leiden, The Netherlands G W Padberg, Department of Neurology, University Medical Centre Nijmegen, NL-6500 HB Nijmegen, The Netherlands

Conflicts of interest: none declared

The first two authors contributed equally to this work. Dr Sandkuij is deceased.

\section{REFERENCES}

1 Rabin M, Wen XL, Hepburn M, Lubs HA, Feldman E, Duara R. Suggestive linkage of developmental dyslexia to chromosome 1p34-p36. Lancet 1993;342:178.

2 Fagerheim T, Raeymaekers $P$, Tonnessen FE, Pedersen M, Tranebjaerg L, Lubs HA. A new gene (DYX3) for dyslexia is located on chromosome 2. J Med Genet 1999:36:664-9.

3 Petryshen TL, Kaplan BJ, Hughes ML, Tzenova J, Field LL. Supportive evidence for the DYX3 dyslexia susceptibility gene in Canadian families. J Med Genet 2002;39:125-6

4 Nopola-Hemmi J, Myllyluoma B, Haltia T, Taipale M, Ollikainen V, Ahonen T, Voutilainen A, Kere J, Widen E. A dominant gene for developmental dyslexia on chromosome 3. J Med Genet 2001;38:658-64.

5 Cardon LR, Smith SD, Fulker DW, Kimberling WJ, Pennington BF, DeFries JC. Quantitative trait locus for reading disability on chromosome 6. Science 1994;266:276-9.

6 Grigorenko EL, Wood FB, Meyer MS, Pauls DL. Chromosome $6 p$ influences on different dyslexia-related cognitive processes: further confirmation. Am J Hum Genet 2000;66:715-23.

7 Kaminen N, Hannula-Jouppi K, Kestila M, Lahermo P, Muller K, Kaaranen M, Myllyluoma B, Voutilainen A, Lyytinen H, Nopola-Hemmi J, Kere J. A genome scan for developmental dyslexia confirms linkage to chromosome $2 \mathrm{p} 11$ and suggests a new locus on 7q32. J Med Genet 2003;40:340-5

8 Grigorenko EL, Wood FB, Meyer MS, Hart LA, Speed WC, Shuster A, Pauls DL. Susceptibility loci for distinct components of developmental dyslexia on chromosomes 6 and 15. Am J Hum Genet 1997;60:27-39.

9 Morris DW, Robinson L, Turic D, Duke M, Webb V, Milham C, Hopkin E, Pound K, Fernando S, Easton M, Hamshere M, Williams N, McGuffin P, Stevenson J, Krawczak M, Owen MJ, O'Donovan MC, Williams J. Familybased association mapping provides evidence for a gene for reading disability on chromosome 15q. Hum Mol Gen 2000;9:843-8.

10 Schulte-Körne G, Grimm T, Nothen MM, Muller-Myhsok B, Cichon S, Vogt IR, Propping $P$, Remschmidt $H$. Evidence for linkage of spelling disability to chromosome 15 [letter]. Am J Hum Genet 1998;63:279-82.

11 Fisher SE, Francks C, Marlow AJ, MacPhie IL, Newbury DF, Cardon LR, Ishikawa-Brush Y, Richardson AJ, Talcott JB, Gayan J, Olson RK, Pennington BF, Smith SD, DeFries JC, Stein JF, Monaco AP. Independent genome-wide scans identify a chromosome 18 quantitative-trait locus influencing dyslexia. Nat Genet 2002;30:86-91.
12 Schulte-Körne G. Annotation: Genetics of reading and spelling disorder. J Child Psychol Psychiatry 2001;42:985-97.

13 Fisher SE, DeFries JC. Developmental dyslexia: genetic dissection of a complex cognitive trait. Nat Rev Neurosci 2002;3:767-80.

14 Taipale M, Kaminen N, Nopola-Hemmi J, Haltia T, Myllyluoma B, Lyytinen H, Muller K, Kaaranen M, Lindsberg PJ, Hannula-Jouppi K, Kere J. A candidate gene for developmental dyslexia encodes a nuclear tetratricopeptide repeat domain protein dynamically regulated in brain. Proc Natl Acad Sci USA 2003;100:11553-8.

15 Blomert L. Stand van zaken indicatiestelling en behandeling van kinderen met dyslexie. In: Reij R, ed. Dyslexie; naar een vergoedingsregeling. Amstelveen: College voor Zorgverzekeringen, 2003:4-112.

16 Wijsman EM, Peterson D, Leutenegger AL, Thomson JB, Goddard KAB, Hsu L, Berninger WW, Raskind WH. Segregation analysis of phenotypic components of learning disabilities. I. Nonword memory and digit span. Am J Hum Genet 2000;67:631-46

17 Pennington BF, Gilger JW, Pauls D, Smith SA, Smith SD, DeFries JC. Evidence for major gene transmission of developmental dyslexia. JAMA 1991;266:1527-34.

18 Raskind WH. Current understanding of the genetic basis of reading and spelling disability. Learn Disabil Q 2001;24:141-57.

19 James WH. The sex-ratio of dyslexic children and their sibs. Dev Med Child Neurol 1992;34:530-3.

20 Kuijpers C, van der Leij A, Been P, van Leeuwen T, ter Keurs M, Schreuder R, van den Bos K. Leesproblemen in de bovenbouw van het voortgezet onderwijs en de volwassenheid: normering van een aantal tests. Pedagogische Studiën 2003;241:272-87.

21 Brus BT. Voeten MJM. Een-minuuttest. Nijmegen: Berkhout, 1973.

22 Van den Bos KP, Lutje Spelberg HC, Scheepstra AJM, De Vries JR. De klepel. Vorm $A$ en $B$. Een test voor de leesvaardigheid van pseudowoorden. Nijmegen: Berkhout, 1994

23 Uterwijk J. WAIS-III Nederlandstalige Bewering. Technische Handleiding Lisse: Swets and Zeitlinger, 2000

24 Wilson AM, Lesaux NK. Persistence of phonological processing deficits in college students with dyslexia who have age-appropriate reading skills. J Learn Disabil 2001;34:394-400.

25 Miller SA, Dykes DD, Polesky HF. A simple salting procedure for extracting DNA from human nucleated cells. Nucleic Acids Res 1988;16:1215.

26 Biosystems PE. ABI prism linkage mapping sets; user's manual The PerkinElmer Corporation, 1999.

27 Van Camp G, Balemans W, Willems PJ. Linkage Designer and Linkage Reporter software for automated gene localization studies. Tech Tips Online 1997; 1:T40013.

28 O'Connell JR, Weeks DE. PedCheck: A program for identification of genotype incompatibilities in linkage analysis. Am J Hum Genet 1998;63:259-66

29 Lathrop GM, Lalouel J-M. Easy calculations of LOD scores and genetic risks on small computers. Am J Hum Genet 1984;36:460-5.

30 Lathrop GM, Lalouel J-M, White RL. Construction of human genetic linkage maps: likelihood calculations for multilocus analysis. Genet Epidemiol 1986;3:39-52.

31 Kong A, Cox NJ. Allele-sharing models: LOD scores and accurate linkage tests. Am J Hum Genet 1997;61:1179-88.

32 International Molecular Genetic Study of Autism Consortium. Further characterization of the autism susceptibility locus AUTS1 on chromosome 7q. Hum Mol Genet 2001;10:973-82.

33 Redolfi E, Pizzuti A, Di Bacco A, Susani L, Labella T, Affer M, Montagna C, Reinbold R, Mumm S, Vezzoni P, Zucchi I. Mapping of the MYCL2 processed gene to Xq22-23 and identification of an additional L MYC-related sequence in Xq27.2. FEBS Lett 1999;446:273-7.

34 Redolfi E, Montagna C, Mumm S, Affer M, Susani L, Reinbold R, Hol F, Vezzoni P, Cimino M, Zucchi I. Identification of CXorf1, a novel intronless gene in Xq27.3, expressed in human hippocampus. DNA Cell Biol 1998; 17:1009-16.

35 Chomez P, De Backer O, Bertrand M, De Plaen E, Boon T, Lucas S. An overview of the MAGE gene family with the identification of all human members of the family. Cancer Res 2001;61:5544-51.

36 Strausberg R. Homo sapiens hypothetical protein FU25736 (FL25736), mRNA. Submitted to Genbank 2002.

37 Nguyen-Ba-Charvet KT, Chedotal A. Role of Slit proteins in the vertebrate brain. J Physiol Paris 2002;96:91-8.

38 Marin O, Plump AS, Flames N, Sanchez-Camacho C, Tessier-Lavigne M, Rubenstein JL. Directional guidance of interneuron migration to the cerebral cortex relies on subcortical Slit1/2-independent repulsion and cortical attraction. Development 2003;130:1889-901.

39 Bardoni B, Mandel JL. Advances in understanding of fragile $X$ pathogenesis and FMRP function, and in identification of $X$ linked mental retardation genes. Curr Opin Genet Dev 2002;12:284-93.

40 deVries BBA, Wiegers AM, Smits APT, Mohkamsing S, Duivenvoorden HJ, Fryns JP, Curfs LMG, Halley DJJ, Oostra BA, van den Ouweland AMW, Niermeijer MF. Mental status of females with an FMRI gene full mutation. Am J Hum Genet 1996;58:1025-32. 